\title{
Clostridium hydrogeniformans sp. nov. and Clostridium cavendishii sp. nov., hydrogen-producing bacteria from chlorinated solvent-contaminated groundwater
}

Correspondence

William M. Moe

moemwil@lsu.edu

\author{
Kimberly S. Bowman, ${ }^{1}$ Rachael E. Dupré, ${ }^{2}$ Fred A. Rainey ${ }^{2}$ \\ and William M. Moe ${ }^{1}$ \\ ${ }^{1}$ Department of Civil and Environmental Engineering, Louisiana State University, Baton Rouge, \\ LA 70803, USA \\ ${ }^{2}$ Department of Biological Sciences, Louisiana State University, Baton Rouge, LA 70803, USA
}

\begin{abstract}
Four hydrogen-producing, aerotolerant, anaerobic bacterial strains isolated from chlorinated solvent-contaminated groundwater were characterized using a polyphasic approach. Three of the strains, designated BL-18, BL-19 and BL-20 ${ }^{\top}$, were found to be identical in $16 \mathrm{~S}$ rRNA gene sequences and in phenotypic properties. Cells of these strains are Gram-positive-staining, sporeforming, motile rods with peritrichous flagella. Growth occurred at $15-40{ }^{\circ} \mathrm{C}, \mathrm{pH} 5.0-10.0$ and at $\mathrm{NaCl}$ concentrations up to $5 \%(\mathrm{w} / \mathrm{v})$. Acid was produced in fermentation of cellobiose, fructose, galactose (weak), glucose, maltose and salicin. Products of fermentation in PYG medium were acetate, butyrate, ethanol, formate, carbon dioxide and hydrogen. Dominant cellular fatty acids when grown in PYG medium were $\mathrm{C}_{13 \text { :0 }}$ iso, $\mathrm{C}_{16: 0}, \mathrm{C}_{13 \text { :0 }}$ anteiso, $\mathrm{C}_{15 \text { :0 }}$ iso and $\mathrm{C}_{15 \text { :0 }}$ anteiso. The genomic DNA G+C content was $30.4 \mathrm{~mol} \%$. These isolates can be differentiated from their closest phylogenetic relative, the cluster I Clostridium species Clostridium frigidicarnis (97.2\% similar to the type strain in 16S rRNA gene sequence), on the basis of phenotypic and chemotaxonomic properties. The other strain characterized in this study, $\mathrm{BL}-28^{\top}$, was Grampositive-staining with spore-forming, rod-shaped cells. Growth occurred at $15-46{ }^{\circ} \mathrm{C}, \mathrm{pH} 6.0-$ 8.5 and at $\mathrm{NaCl}$ concentrations up to $3 \%(\mathrm{w} / \mathrm{v})$. Acid was produced from cellobiose, dextran, fructose (weak), glucose, maltose, salicin and trehalose. End products of PYG fermentation included acetate, butyrate, pyruvate, carbon dioxide and hydrogen. Dominant cellular fatty acids from cells grown in PYG medium at $30{ }^{\circ} \mathrm{C}$ were $\mathrm{C}_{14: 0}, \mathrm{C}_{14: 0}$ dimethyl aldehyde, $\mathrm{C}_{16: 0}$ and $\mathrm{C}_{12: 0}$. The DNA G+C content was 28.5 mol\%. Phylogenetic analysis based on $16 \mathrm{~S}$ rRNA gene sequences revealed that strain BL-28 ${ }^{\top}$ falls within cluster I of the genus Clostridium, but with $\leqslant 95.2 \%$ identity with previously described species. On the basis of results presented here, strains BL-20 ${ }^{\top}$ (=NRRL B $-51348^{\top}=$ DSM $\left.21757^{\top}\right)$ and BL-28 ${ }^{\top}\left(=N R R L B-51352^{\top}=\mathrm{DSM}\right.$ $21758^{\top}$ ) are proposed as the type strains of novel species of the genus Clostridium with the names Clostridium hydrogeniformans sp. nov. and Clostridium cavendishii sp. nov., respectively.
\end{abstract}

During a study aimed at characterizing the microbial population in groundwater contaminated with chlorinated solvents at the PetroProcessors of Louisiana, Inc. (PPI) Superfund Site located near Baton Rouge, LA, USA, 168 bacterial strains that grouped phylogenetically in 18 operational taxonomic units (OTUs) were isolated

The GenBank/EMBL/DDBJ accession numbers for the $16 \mathrm{~S}$ rRNA gene sequences of strains $\mathrm{BL}-20^{\top}$ and $\mathrm{BL}-28^{\top}$ are $\mathrm{DQ} 196623$ and DQ196621, respectively.

The fatty acid profile of strain BL-28 ${ }^{\top}$ is available as supplementary material with the online version of this paper.
(Bowman et al., 2006). Of these, strain BL-18 was isolated on R2A agar (Difco) supplemented with L-cysteine hydrochloride $\left(0.5 \mathrm{~g} \mathrm{l}^{-1}\right)$ as a reductant and resazurin $\left(1.0 \mathrm{mg} \mathrm{l}^{-1}\right)$ as a redox indicator, adjusted to $\mathrm{pH} 7.0$ prior to autoclaving, and incubated at $30{ }^{\circ} \mathrm{C}$ in an anaerobic chamber (Coy Laboratory Products) supplied with a gas headspace composed of $90 \% \mathrm{~N}_{2}, 5 \% \mathrm{CO}_{2}$ and $5 \% \mathrm{H}_{2}$. Strains BL-19 and BL-20 $0^{\mathrm{T}}$ were isolated on plate count agar (PCA; Difco) amended with the same supplements and under the same incubation conditions. Strain $\mathrm{BL}-28^{\mathrm{T}}$ was isolated on Columbia anaerobe $5 \%$ sheep blood agar (CSBA; BD Diagnostics) under the same incubation 
conditions. Purity of the strains was verified by microscopy after multiple transfers. Strains were preserved at $-80{ }^{\circ} \mathrm{C}$ in R2A medium (formulation of R2A agar but without solidifying agent) supplemented with $5 \%(\mathrm{v} / \mathrm{v})$ DMSO.

To characterize their potential role in supporting chlorinated solvent transformation at the site from which they were isolated, strains $\mathrm{BL}-20^{\mathrm{T}}$ and $\mathrm{BL}-28^{\mathrm{T}}$ were tested to determine their abilities to dechlorinate and their ability to produce hydrogen and grow in the presence of tetrachloroethene (PCE), 1,2-dichloroethane (1,2-DCA) and 1,1,2trichloroethane (1,1,2-TCA). Neither strain dechlorinated the solvents tested, but both strains were found to produce hydrogen even when grown in the presence of nearsaturation concentrations of PCE $(1.1 \mathrm{mM})$ and high concentrations of 1,2-DCA (22.2 and $19.8 \mathrm{mM}$ for BL-20 and $\mathrm{BL}-28^{\mathrm{T}}$, respectively) and 1,1,2-TCA (4.9 and $\left.7.4 \mathrm{mM}\right)$ (Bowman et al., 2009). Here, we report the polyphasic characterization of these isolates and establish their taxonomic status. For comparative purposes, Clostridium frigidicarnis DSM $12271^{\mathrm{T}}$, obtained from the Deutsche Sammlung von Mikroorganismen und Zellkulturen $\mathrm{GmbH}$, Braunschweig, Germany, was included in testing.

All described procedures followed strict anaerobic protocols as described in Holdeman et al. (1977). Unless stated otherwise, all tests were carried out in duplicate in anaerobic PY broth with $1 \%(\mathrm{w} / \mathrm{v})$ glucose adjusted to $\mathrm{pH} 7.0$ with headspace gas purged with ultra-high-purity nitrogen prior to autoclaving (Holdeman et al., 1977). Colony morphology was observed after growth on anaerobic CSBA incubated for $48 \mathrm{~h}$ at $37{ }^{\circ} \mathrm{C}$. Cells grown in PYG broth incubated for $18 \mathrm{~h}$ at $30{ }^{\circ} \mathrm{C}$ were Gram-stained using the method of Johnson et al. (1995). The Gram type was confirmed using the $\mathrm{KOH}$ procedure of Powers (1995). Cell morphology was determined using phase-contrast and DIC light microscopy (Nikon Microphot-FXA) and transmission electron microscopy (JEOL 100-CX TEM). Vegetative cells were imaged after $18 \mathrm{~h}$ of incubation and spores after 5 days of incubation at $30{ }^{\circ} \mathrm{C}$ in anaerobic PYG broth. Motility was assessed by microscope observations and stab inoculation of $0.4 \%$ (w/v) semi-solid PYG agar incubated at $37{ }^{\circ} \mathrm{C}$ (Gerhardt et al., 1981).

The temperature range for growth was assessed in PYG broth incubated at temperatures ranging from 4 to $50{ }^{\circ} \mathrm{C}$ for 21 days. The salinity range for growth was tested in PYG broth amended with $1,2,3,4,5$ and $6 \%(\mathrm{w} / \mathrm{v}) \mathrm{NaCl}$ incubated at $30{ }^{\circ} \mathrm{C}$ for 14 days. The $\mathrm{pH}$ range for growth was assessed at $25{ }^{\circ} \mathrm{C}$ in PYG medium buffered as described by Lee et al. (2007) with 14 days of incubation. The ability of strains to grow in PYG medium with no oxygen, with $5 \%$ oxygen and with $21 \%$ oxygen in the headspace was assessed following incubation at $37{ }^{\circ} \mathrm{C}$ for 7 days. The ability to utilize cellobiose, microgranular cellulose (Sigma) and Avicel microcrystalline cellulose (type PH-105, lot no. 50630C; FMC BioPolymer) was evaluated in modified CM3 medium prepared as described by Ren et al. (2007), adjusted to $\mathrm{pH} 6.5$, and incubated at $30{ }^{\circ} \mathrm{C}$ for 21 days. Exponentially growing cultures diluted to an $\mathrm{OD}_{600}$ of 0.05 were used for inoculation $(2 \% \mathrm{v} / \mathrm{v})$. Growth was measured spectrophotometrically at $600 \mathrm{~nm}$ (Evolution 60; Thermo Scientific). Cultures exhibiting an $\mathrm{OD}_{600} \geqslant 0.05$ units higher than uninoculated negative controls were recorded as positive for growth.

The ability of the strains to utilize various substrates was determined in duplicate in anaerobic PY broth as described by Holdeman et al. (1977) with cellobiose, dextran, fructose, galactose, glucose, inositol, inulin, lactose, maltose, mannitol, raffinose, rhamnose, salicin, sorbitol, sorbose, sucrose and xylose at $1 \%(\mathrm{w} / \mathrm{v})$ and adonitol, arabinose and trehalose at $0.5 \%(\mathrm{w} / \mathrm{v})$. Growth was evaluated by a decrease in $\mathrm{pH}$, as described by Holdeman et al. (1977), after incubation at $30{ }^{\circ} \mathrm{C}$ for 10 days.

Tests for gelatin, aesculin and starch hydrolysis, lecithinase and catalase activity, milk reaction and hydrogen sulfide production were performed following methods described previously (Holdeman et al., 1977). Additional biochemical features were tested using the Rapid ID 32A system (bioMérieux) according to the manufacturer's recommended protocol.

Fermentation products were determined in PYG broth incubated at $30{ }^{\circ} \mathrm{C}$ for 6 days. Exponentially growing cultures diluted to an $\mathrm{OD}_{600}$ of 0.05 were used to inoculate $(2 \%, \mathrm{v} / \mathrm{v})$ serum bottles containing $100 \mathrm{ml}$ liquid medium and $60 \mathrm{ml}$ gas headspace. Acetate, butyrate, formate, lactate, propionate and pyruvate were analysed by ion chromatography (DX500; Dionex) as described by Lin et al. (2007). Ethanol and butanol were determined using purge and trap gas chromatography with a flame-ionization detector as described by Yan et al. (2009). Gas production volume was measured as described by Owen et al. (1979). Hydrogen and carbon dioxide concentrations in the headspace gas were analysed by gas chromatography as described by Van Ginkel et al. (2001).

Hydrogen yield from glucose fermentation was assessed as described by Van Ginkel et al. (2001) but with the medium supplemented with yeast extract $\left(0.5 \mathrm{~g} \mathrm{l}^{-1}\right)$ and resazurin $\left(1.0 \mathrm{mg} \mathrm{l}^{-1}\right)$, the $\mathrm{pH}$ adjusted to 7.0 and with the headspace gas purged with ultra-high-purity nitrogen prior to autoclaving.

For cellular fatty acid analyses, cells grown in PYG broth at $30{ }^{\circ} \mathrm{C}$ were harvested in mid-exponential growth phase by centrifugation at $8000 \mathrm{~g}$ for $15 \mathrm{~min}$. Cellular fatty acids were extracted from the cell pellet, saponified and methylated at the BCCM/LMG (Ghent, Belgium) following the Sherlock Microbial Identification System recommended protocol (MIDI) and then analysed by gas chromatography (Sasser, 1990). Compounds were identified using the MIDI MOORE library version 5.0 (for VPI broth-grown anaerobes in PYG broth). Genomic DNA $\mathrm{G}+\mathrm{C}$ content was determined at the BCCM/LMG using the HPLC technique of Mesbah et al. (1989).

Genomic DNA extraction, PCR and sequencing of $16 \mathrm{~S}$ rRNA genes were performed as described by Bowman et al. 
(2006). The resulting sequences were verified manually. Pairwise nucleotide similarity values were obtained from EzTaxon analysis on nearly complete sequences for BL- $20^{\mathrm{T}}$ (1454 bp) and BL-28 (1452 bp) (http://www.eztaxon.org/; Chun et al., 2007). A phylogenetic tree (Fig. 1) was constructed as described by Bowman et al. (2009).

On anaerobic CSBA medium, strains BL-18, BL-19 and $\mathrm{BL}-20^{\mathrm{T}}$ formed colonies that were circular with entire margins, convex, creamy opaque and $1.5-3.5 \mathrm{~mm}$ in diameter after $48 \mathrm{~h}$ at $37{ }^{\circ} \mathrm{C}$. Under the same conditions, strain $\mathrm{BL}-28^{\mathrm{T}}$ formed colonies that were irregular with undulate to lobate margins, convex, creamy white, semiopaque to translucent and 3-6 $\mathrm{mm}$ in diameter. All four strains also grew well on anaerobic PCA.

Cells of strains BL-18, BL-19 and BL-20 ${ }^{\mathrm{T}}$ were Grampositive-staining, motile rods, $0.7-1.1 \mu \mathrm{m}$ in diameter and 2.0-5.5 $\mu \mathrm{m}$ long, with peritrichous flagella. Spores of BL$18, \mathrm{BL}-19$ and $\mathrm{BL}-20^{\mathrm{T}}$ were oval and subterminal. Cells of BL- $28^{\mathrm{T}}$ were Gram-positive-staining rods, $0.4-1.0 \mu \mathrm{m}$ in diameter and 2.2-10.0 $\mu \mathrm{m}$ long, with oval, terminal spores. Motility of cells of strain BL- $28^{\mathrm{T}}$ was not observed with light microscopy and no flagella were observed through TEM. In stab inoculation of semi-solid PYG agar, however, strain $\mathrm{BL}-28^{\mathrm{T}}$ grew quickly throughout the medium.

The temperature range for growth of strains BL-18, BL-19 and $\mathrm{BL}-20^{\mathrm{T}}$ was $15-40{ }^{\circ} \mathrm{C}$, with optimum growth between 30 and $40{ }^{\circ} \mathrm{C}$. No growth was detected at 10 or $43^{\circ} \mathrm{C}$. Strain BL-28 ${ }^{\mathrm{T}}$ grew between 15 and $46{ }^{\circ} \mathrm{C}$, with optimum growth between 37 and $46{ }^{\circ} \mathrm{C}$. Growth was not observed at 10 or $50{ }^{\circ} \mathrm{C}$.
Strains BL-18, BL-19 and BL-20 ${ }^{\mathrm{T}}$ grew in $\mathrm{NaCl}$ concentrations ranging from 0 to $5 \%$; no growth was detected in the presence of $6 \% \mathrm{NaCl}$. BL- $28^{\mathrm{T}}$ grew in $0-3 \% \mathrm{NaCl}$, but not in $4 \% \mathrm{NaCl}$. All four strains grew optimally when no additional $\mathrm{NaCl}$ was added to the PYG medium.

The $\mathrm{pH}$ range for growth of strains BL-18, BL-19 and BL-20 ${ }^{\mathrm{T}}$ was $\mathrm{pH}$ 5.0-10.0, with optimum growth at $\mathrm{pH}$ 6.9-8.9. Growth was not detected at or below $\mathrm{pH} 4.0$ or at or above $\mathrm{pH}$ 11.0. The $\mathrm{pH}$ range for growth of $\mathrm{BL}-28^{\mathrm{T}}$ was $\mathrm{pH} 6.0$ 8.5, with optimum growth at $\mathrm{pH}$ 6.9-8.0. No growth was observed at or below $\mathrm{pH} 5.0$ or at or above $\mathrm{pH} 9.0$.

In PYG medium, all strains grew well in the absence of oxygen and in the presence of $5 \%$ oxygen (tested with five consecutive transfers). None of the strains grew in the presence of atmospheric oxygen levels $(21 \%, \mathrm{v} / \mathrm{v})$.

Physiological properties of strains BL-18, BL-19 and BL$20^{\mathrm{T}}$ were identical and are contained in the species description and in Table 1. Physiological properties of strain $\mathrm{BL}-28^{\mathrm{T}}$ are contained in the species description. The ability of the strains to grow in the presence of chlorinated solvents, as reported in the species descriptions, was determined previously (Bowman et al., 2009).

The end products of fermentation in PYG medium for strain $\mathrm{BL}-20^{\mathrm{T}}$ included acetate $(13.1 \mathrm{mM})$, butyrate $(2.0 \mathrm{mM})$, formate $(2.1 \mathrm{mM})$, ethanol $(0.4 \mathrm{mM})$ and trace amounts $(<0.1 \mathrm{mM})$ of butanol. For $\mathrm{BL}-28^{\mathrm{T}}$, the end products of fermentation in PYG were acetate $(4.9 \mathrm{mM})$, butyrate $(4.8 \mathrm{mM})$ and pyruvate $(1.6 \mathrm{mM})$ and trace amounts $(<0.1 \mathrm{mM})$ of ethanol and butanol. Hydrogen and carbon dioxide accumulated in the headspace as

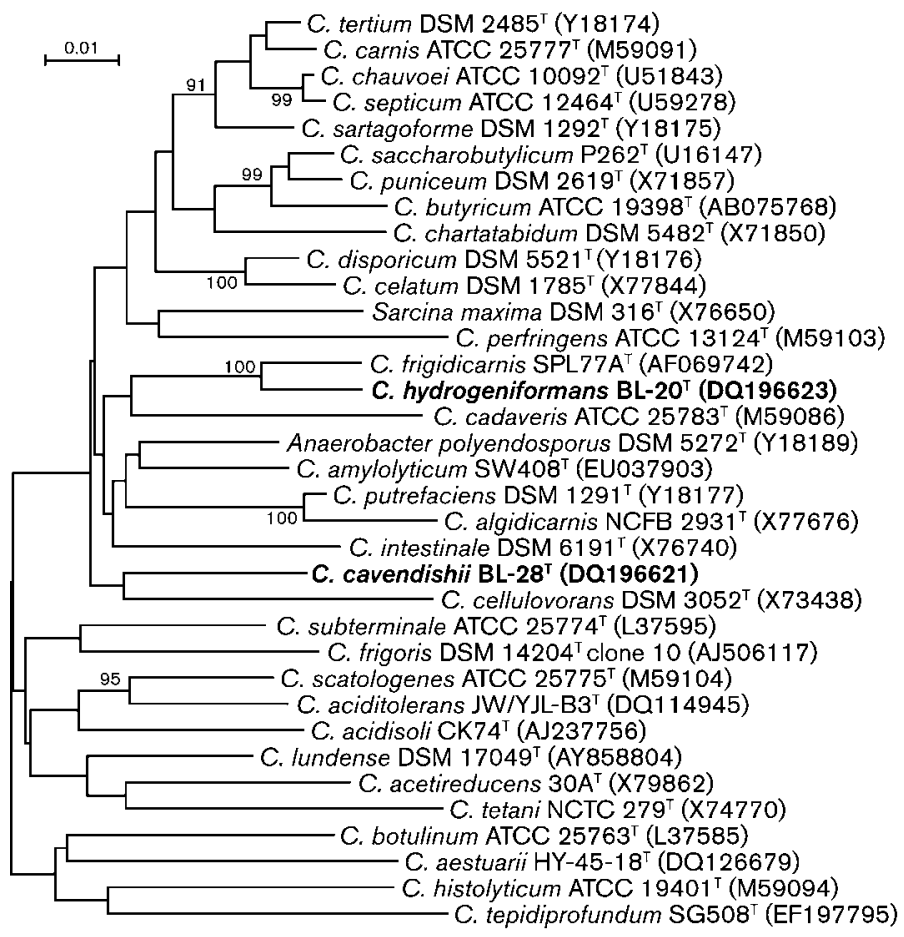

Fig. 1. Neighbour-joining phylogenetic tree showing the relatedness of strains $B L-20^{\top}$ and $B L-28^{\top}$ to members of the genus Clostridium based on 16S rRNA gene sequences. Bar, 1 substitution per 100 nucleotide positions. Bootstrap values for nodes with significant support $(>90 \%)$ are indicated by numbers located at branching points. 
Table 1. Properties that differentiate strain $B L-20^{\top}$ from $C$. frigidicarnis DSM $12271^{\top}$

All data were determined in this study except for the DNA G +C content of C. frigidicarnis DSM $12271^{\mathrm{T}}$, which was reported previously (Broda et al., 1999).

\begin{tabular}{|lcc|}
\hline Characteristic & BL-20 & $\begin{array}{c}\text { C. } \text { frigidicarnis }^{\mathbf{T}} \\
\text { DSM 12271 }\end{array}$ \\
\hline Cell size $(\mu \mathrm{m})$ & $0.7-1.1 \times 2.0-5.5$ & $1.2-1.6 \times 4.3-8.7$ \\
DNA G + C content (mol\%) & 30.4 & 27.3 \\
Minimum temperature for & 15 & 4 \\
growth $\left({ }^{\circ} \mathrm{C}\right)$ & & \\
Utilization of: & + & - \\
Salicin & - & + \\
Sorbitol & - & + \\
Trehalose & Curdled & Curdled/digested \\
Milk reaction & & + \\
Activity of: & - & - \\
Lecithinase & + & - \\
$\alpha$-Glucosidase & + & + \\
$\beta$-Glucosidase & - & \\
Proline arylamidase & & \\
\hline
\end{tabular}

fermentation products for all strains tested. The yield (mol hydrogen produced per mol glucose consumed) was 1.4 for $\mathrm{BL}-20^{\mathrm{T}}$ and 1.1 for BL- $28^{\mathrm{T}}$.

The DNA G $+\mathrm{C}$ contents of strains $\mathrm{BL}-20^{\mathrm{T}}$ and $\mathrm{BL}-28^{\mathrm{T}}$ determined by HPLC were 30.4 and $28.5 \mathrm{~mol} \%$, respectively. Cellular fatty acids of strains BL- $20^{\mathrm{T}}$ and $\mathrm{BL}-28^{\mathrm{T}}$ are reported in Table 1 and Supplementary Table S1 (available in IJSEM Online), respectively.

Nearly complete $16 \mathrm{~S}$ rRNA gene sequences were determined for all four strains. All four strains were placed within the radiation of cluster I of the genus Clostridium as defined by Collins et al. (1994). Sequences of BL-18, BL-19 and $\mathrm{BL}-20^{\mathrm{T}}$ were identical and were most closely related to the sequences of Clostridium frigidicarnis DSM $12271^{\mathrm{T}}$ (97.2\% identity), Clostridium septicum ATCC $12464^{\mathrm{T}}$ $(94.7 \%)$ and Clostridium chauvoei ATCC $10092^{\mathrm{T}}$ $(94.7 \%)$ (Fig. 1). On the basis of $16 \mathrm{~S}$ rRNA gene sequences, strain BL-28 ${ }^{\mathrm{T}}$ was found to be only distantly related to previously described Clostridium species. The highest sequence identity of strain $\mathrm{BL}-28^{\mathrm{T}}$ was with Clostridium amylolyticum SW $408^{\mathrm{T}}(95.2 \%)$, Clostridium sartagoforme DSM $1292^{\mathrm{T}}$ (95.1\%), Anaerobacter polyendosporous $(94.8 \%)$, Clostridium diolis DSM $5431^{\mathrm{T}}$ (94.7\%) and Clostridium tertium DSM $2485^{\mathrm{T}}$ (94.7\%). However, strain $\mathrm{BL}-28^{\mathrm{T}}$ branched with Clostridium cellulovorans DSM $3052^{\mathrm{T}}$ on the phylogenetic tree, but shared only $94.5 \%$ identity.

Based on their identical phenotypes and 16S rRNA gene sequences, strains BL-18, BL-19 and BL- $20^{\mathrm{T}}$ are assigned to the same species, represented by the type strain BL- $20^{\mathrm{T}}$. The clustering of $\mathrm{BL}-20^{\mathrm{T}}$ with C. frigidicarnis DSM $12271^{\mathrm{T}}$ is supported by a bootstrap value of $100 \%$. Strain BL- $20^{\mathrm{T}}$ is clearly differentiated from its closest phylogenetic relative, C. frigidicarnis, based on cell size and genotypic and physiological differences (Table 1). Further differences are evident in the cellular fatty acid profiles of BL- $20^{\mathrm{T}}$ and $C$. frigidicarnis DSM $12271^{\mathrm{T}}$ when grown under identical conditions (Table 2). Of the major cellular fatty acids produced $(\geqslant 10 \%)$, only $\mathrm{C}_{16: 0}\left(12.9 \%\right.$ for $\mathrm{BL}-20^{\mathrm{T}}, 13.2 \%$ for C. frigidicarnis DSM $12271^{\mathrm{T}}$ ) was produced by both strains. The other primary fatty acids produced by strain BL- $20^{\mathrm{T}}$ were $\mathrm{C}_{13: 0}$ iso $(16.2 \%), \mathrm{C}_{13: 0}$ anteiso $(12.1 \%)$, $\mathrm{C}_{15: 0}$ iso $(11.0 \%)$ and $\mathrm{C}_{15: 0}$ anteiso $(10.0 \%)$. In contrast, C. frigidicarnis DSM $12271^{\mathrm{T}}$ contained large proportions of $\mathrm{C}_{14: 0}(37.2 \%)$ and $\mathrm{C}_{16: 1} \omega 7 c(26.8 \%)$.

$16 \mathrm{~S}$ rRNA gene sequence analysis revealed that $\mathrm{BL}-28^{\mathrm{T}}$ branched with C. cellulovorans DSM $3052^{\mathrm{T}}$, but the pairwise sequence identity of BL- $28^{\mathrm{T}}$ with C. cellulovorans DSM $3052^{\mathrm{T}}$ was lower $(94.5 \%)$ than with other Clostridium relatives (e.g. C. amylolyticum SW $408^{\mathrm{T}}$; $95.2 \%)$. Low bootstrap support (44\%) for the branching

Table 2. Comparison of cellular fatty acid compositions of strains $\mathrm{BL}-20^{\top}$ and C. frigidicarnis DSM $12271^{\top}$

Values are percentages of total fatty acids and were determined in this study; fatty acids occurring at less than $1 \%$ in both strains are not listed. - , Not detected $(<1 \%)$. DMA, Dimethyl aldehyde.

\begin{tabular}{|lcc|}
\hline Fatty acid & BL-20 $^{\text {T }}$ & $\begin{array}{c}\text { C. frigidicarnis } \\
\text { DSM } \mathbf{~ 1 2 2 7 1 ~}^{\mathbf{T}}\end{array}$ \\
\hline $\mathrm{C}_{12: 0}$ iso & 1.3 & - \\
$\mathrm{C}_{12: 0}$ & 2.3 & 1.1 \\
$\mathrm{C}_{13: 0}$ iso & 16.2 & - \\
$\mathrm{C}_{13: 0}$ anteiso & 12.1 & - \\
$\mathrm{C}_{14: 0}$ iso & 5.1 & 2.8 \\
$\mathrm{C}_{14: 0}$ & 6.4 & 37.2 \\
$\mathrm{C}_{14: 0}$ DMA & 1.6 & - \\
$\mathrm{C}_{15: 0}$ iso & 11.0 & 2.0 \\
$\mathrm{C}_{15: 0}$ anteiso & 10.0 & 2.3 \\
Summed feature $^{*}$ & - & 1.5 \\
$\mathrm{C}_{16: 0}$ aldehyde & 1.0 & - \\
$\mathrm{C}_{15: 0}$ iso DMA & 2.0 & - \\
${\text { Summed feature } 13^{*}}_{\mathrm{C}_{16: 0} \text { iso }}$ & 1.2 & - \\
$\mathrm{C}_{16: 1} \omega 9 c$ & 1.4 & - \\
$\mathrm{C}_{16: 1} \omega 7 c$ & - & 1.7 \\
$\mathrm{C}_{16: 1} \omega 5 c$ & - & 3.3 \\
$\mathrm{C}_{16: 0}$ & - & 13.2 \\
$\mathrm{C}_{16: 0}$ DMA & 12.9 & - \\
$\mathrm{C}_{16: 1} \omega 7 c$ DMA & 4.4 & - \\
$\mathrm{C}_{17: 0}$ iso & - & - \\
$\mathrm{C}_{17: 0}$ anteiso & 2.2 & - \\
$\mathrm{C}_{18: 0}$ & 1.5 & \\
\hline
\end{tabular}

*Summed feature 4 contains one or more of unknown ECL 14.762, $\mathrm{C}_{15: 2}$ and $\mathrm{C}_{15: 1} \omega 8 c$. Summed feature 13 contains $\mathrm{C}_{15: 0}$ anteiso DMA and/or $\mathrm{C}_{14: 0} 2-\mathrm{OH}$. 
provides further evidence that strain $\mathrm{BL}-28^{\mathrm{T}}$ is phylogenetically divergent from C. cellulovorans and other members of Clostridium cluster I. Phenotypically, BL- $28^{\mathrm{T}}$ may be differentiated from C. cellulovorans on the basis that the latter grows on cellulose, galactose, lactose and sucrose (Sleat et al., 1984), while BL- $28^{\mathrm{T}}$ did not utilize these substrates. Additionally, BL- $28^{\mathrm{T}}$ grew on trehalose, but $C$. cellulovorans does not.

On the basis of phylogenetic, chemotaxonomic and phenotypic features obtained in this study, we propose that strains $\mathrm{BL}-20^{\mathrm{T}}$ and $\mathrm{BL}-28^{\mathrm{T}}$ each represent novel species within cluster I of the genus Clostridium. The names proposed for these novel species are Clostridium hydrogeniformans sp. nov. for strain $\mathrm{BL}-20^{\mathrm{T}}$ and Clostridium cavendishii sp. nov. for strain BL- $28^{\mathrm{T}}$.

\section{Description of Clostridium hydrogeniformans sp. nov.}

Clostridium hydrogeniformans (hy.dro.ge.ni.for'mans. N.L. $\mathrm{n}$. hydrogenum hydrogen; L. part. adj. formans forming; N.L. part. adj. hydrogeniformans hydrogen-forming).

Cells are Gram-positive-staining, motile rods (0.7$1.1 \times 2.0-5.5 \mu \mathrm{m})$ with peritrichous flagella. They form oval, subterminal spores. Colonies grown on anaerobic CSBA are convex, circular, creamy and opaque with entire margins. Aerotolerant anaerobes. Grows at $15-40{ }^{\circ} \mathrm{C}$, with optimum growth at $30-40{ }^{\circ} \mathrm{C}$. In PYG medium, grows at $\mathrm{NaCl}$ concentrations up to $5 \%(\mathrm{w} / \mathrm{v})$. The $\mathrm{pH}$ range for growth at $25{ }^{\circ} \mathrm{C}$ is $\mathrm{pH} 5.0-10.0$, with optimum growth at pH 6.9-8.9. Ferments cellobiose, fructose, galactose (weak), glucose, maltose and salicin, but not adonitol, arabinose, cellulose, dextran, inositol, inulin, lactose, mannitol, rhamnose, sorbitol, sorbose, sucrose, trehalose or xylose. Hydrolyses gelatin and aesculin but not starch. Produces hydrogen sulfide. Negative for lecithinase and catalase activities. Milk is curdled. In the Rapid ID 32A system, positive results are observed for D-mannose and raffinose (weak) fermentation and for $\alpha$-glucosidase, $\beta$ glucosidase and pyroglutamic acid arylamidase activities, but negative results are observed for nitrate reduction, indole production, activity of alkaline phosphatase, $\alpha$ arabinosidase, arginine dihydrolase, $\alpha$-fucosidase, $\alpha$-galactosidase, $\beta$-galactosidase, $\beta$-galactosidase 6 -phosphate, $\beta$ glucuronidase, glutamic acid decarboxylase, $N$-acetyl- $\beta$ glucosaminidase and urease and activity of the following arylamidases: alanine, arginine, glutamyl glutamic acid, glycine, histidine, leucine, leucyl glycine, phenylalanine, proline, serine and tyrosine. Products of fermentation in PYG medium are acetate, butyrate, ethanol, formate, hydrogen and carbon dioxide. Dominant cellular fatty acids of cells grown in PYG medium at $30{ }^{\circ} \mathrm{C}$ are $\mathrm{C}_{13: 0}$ iso, $\mathrm{C}_{16: 0}, \mathrm{C}_{13: 0}$ anteiso, $\mathrm{C}_{15: 0}$ iso and $\mathrm{C}_{15: 0}$ anteiso. Grows and produces hydrogen in the presence of near-saturation concentrations of tetrachloroethene $(1.1 \mathrm{mM})$ and high concentrations of 1,2-dichloroethane (22.2 $\mathrm{mM})$ and 1,1,2trichloroethane $(4.9 \mathrm{mM})$.
The type strain, BL-20 $0^{\mathrm{T}}$ (=DSM $21757^{\mathrm{T}}=\mathrm{NRRL}$ B$51348^{\mathrm{T}}$ ), was isolated from groundwater. The DNA G+C content of the type strain is $30.4 \mathrm{~mol} \%$.

\section{Description of Clostridium cavendishii sp. nov.}

Clostridium cavendishii [ca.ven.di'shi.i. N.L. masc. gen. n. cavendishii of Cavendish, named after Henry Cavendish (1731-1810), the British chemist who has been credited with the discovery of hydrogen].

Cells are Gram-positive-staining rods $(0.4-1.0 \times 2.2-$ $10.0 \mu \mathrm{m})$ that form terminal spores. Colonies grown on anaerobic CSBA are irregular with undulate to lobate margins, convex, creamy white and semi-opaque to translucent. Aerotolerant anaerobe. Temperature range for growth is $15-46{ }^{\circ} \mathrm{C}$, with optimum growth at $37-$ $46{ }^{\circ} \mathrm{C}$. In PYG medium, grows in the presence of up to $3 \%$ $(\mathrm{w} / \mathrm{v}) \mathrm{NaCl}$. The $\mathrm{pH}$ range for growth at $25{ }^{\circ} \mathrm{C}$ is $\mathrm{pH} 6.0$ 8.5, with optimum growth at $\mathrm{pH}$ 6.9-8.0. Ferments cellobiose, dextran, fructose (weak), glucose, maltose, salicin and trehalose but not adonitol, arabinose, cellulose, galactose, inositol, inulin, lactose, mannitol, raffinose, rhamnose, sorbitol or sucrose. Hydrolyses aesculin, but not gelatin or starch. Does not produce hydrogen sulfide. Positive for lecithinase but not catalase. No reaction in milk. In the Rapid ID 32A test system, positive for $\beta$ galactosidase (weak), $\alpha$-glucosidase and pyroglutamic acid arylamidase activity, but negative results are observed for nitrate reduction, indole production, fermentation of mannose and raffinose, activity of alkaline phosphatase, $\alpha$-arabinosidase, arginine dihydrolase, $\alpha$-fucosidase, $\alpha$ galactosidase, $\beta$-galactosidase 6 -phosphate, $\beta$-glucosidase, $\beta$-glucuronidase, glutamic acid decarboxylase, $N$-acetyl $-\beta$ glucosaminidase and urease and activities of the following arylamidases: alanine, arginine, glutamyl glutamic acid, glycine, histidine, leucine, leucyl glycine, phenylalanine, proline, serine and tyrosine. End products of fermentation in PYG medium include acetate, butyrate, pyruvate, hydrogen and carbon dioxide. Dominant cellular fatty acids from cells growing exponentially in PYG medium at $30{ }^{\circ} \mathrm{C}$ are $\mathrm{C}_{14: 0}, \mathrm{C}_{14: 0}$ dimethyl aldehyde, $\mathrm{C}_{16: 0}$ and $\mathrm{C}_{12: 0}$. Produces hydrogen when grown in the presence of nearsaturation concentrations of PCE $(1.1 \mathrm{mM})$ and high concentrations of 1,2-dichloroethane $(19.8 \mathrm{mM})$ and 1,1,2trichloroethane $(7.4 \mathrm{mM})$.

The type strain, BL-28 ${ }^{\mathrm{T}}$ (=DSM $21758^{\mathrm{T}}=\mathrm{NRRL}$ B$51352^{\mathrm{T}}$ ), was isolated from groundwater. The DNA G $+\mathrm{C}$ content for the type strain is $28.5 \mathrm{~mol} \%$.

\section{Acknowledgements}

This research was funded by the Governor's Biotechnology Initiative of the Louisiana Board of Regents (grant BOR\#015) and NPC Services, Inc. The authors thank Cindy Henk of the LSU Socolofsky Microscopy Center for assistance with microscopy and Jean Euzéby for assistance with the etymology of the new names. 


\section{References}

Bowman, K. S., Moe, W. M., Rash, B. A., Bae, H.-S. \& Rainey, F. A. (2006). Bacterial diversity of an acidic Louisiana groundwater contaminated by dense nonaqueous-phase liquid containing chloroethanes and other solvents. FEMS Microbiol Ecol 58, 120-133.

Bowman, K. S., Moe, W. M. \& Rainey, F. A. (2009). Production of hydrogen by Clostridium species in the presence of chlorinated solvents. FEMS Microbiol Lett 290, 188-194.

Broda, D. M., Lawson, P. A., Bell, R. G. \& Musgrave, D. R. (1999). Clostridium frigidicarnis sp. nov., a psychrotolerant bacterium associated with 'blown pack' spoilage of vacuum-packed meats. Int J Syst Bacteriol 49, 1539-1550.

Chun, J., Lee, J.-H., Jung, Y., Kim, M., Kim, S., Kim, B. K. \& Lim, Y. W. (2007). EzTaxon: a web-based tool for the identification of prokaryotes based on $16 \mathrm{~S}$ ribosomal RNA gene sequences. Int J Syst Evol Microbiol 57, 2259-2261.

Collins, M. D., Lawson, P. A., Willems, A., Cordoba, J. J., FernandezGarayzabal, J., Garcia, P., Cai, J., Hippe, H. \& Farrow, J. A. E. (1994). The phylogeny of the genus Clostridium: proposal of five new genera and eleven new species combinations. Int J Syst Bacteriol 44, 812-826.

Gerhardt, P., Murray, R. G. E., Costilow, R. N., Nester, E. W., Wood, W. A., Krieg, N. R. \& Phillips, G. B. (editors) (1981). Manual of Methods for General Bacteriology. Washington, DC: American Society for Microbiology.

Holdeman, L. V., Cato, E. P. \& Moore, W. E. C. (1977). Anaerobe Laboratory Manual, 4th edn. Blacksburg, VA: Virginia Polytechnic Institute and State University.

Johnson, M. J., Thatcher, E. \& Cox, M. E. (1995). Techniques for controlling variability in gram staining of obligate anaerobes. J Clin Microbiol 33, 755-758.

Lee, Y. J., Romanek, C. S. \& Wiegel, J. (2007). Clostridium aciditolerans sp. nov., an acid-tolerant spore-forming anaerobic bacterium from constructed wetland sediment. Int $J$ Syst Evol Microbiol 57, 311-315.

Lin, P.-Y., Whang, L.-M., Wu, Y.-R., Ren, W.-J., Hsiao, C.-J., Li, S.-L. \& Chang, J.-S. (2007). Biological hydrogen production of the genus Clostridium: metabolic study and mathematical model simulation. Int J Hydrogen Energy 32, 1728-1735.

Mesbah, M., Premachandran, U. \& Whitman, W. B. (1989). Precise measurement of the $\mathrm{G}+\mathrm{C}$ content of deoxyribonucleic acid by high-performance liquid chromatography. Int J Syst Bacteriol 39, 159167.

Owen, W. F., Stuckey, D. C., Healy, J. B., Jr, Young, L. Y. \& McCarty, P. L. (1979). Bioassay for monitoring biochemical methane potential and anaerobic toxicity. Water Res 13, 485-492.

Powers, E. M. (1995). Efficacy of the Ryu nonstaining $\mathrm{KOH}$ technique for rapidly determining gram reactions of food-borne and waterborne bacteria and yeasts. Appl Environ Microbiol 61, 3756-3758.

Ren, Z., Ward, T. W., Logan, B. E. \& Regan, J. M. (2007). Characterization of the cellulolytic and hydrogen-producing activities of six mesophilic Clostridium species. J Appl Microbiol 103, 22582266.

Sasser, M. (1990). Identification of bacteria by gas chromatography of cellular fatty acids, MIDI Technical Note 101. Newark, DE: MIDI Inc.

Sleat, R., Mah, R. A. \& Robinson, R. (1984). Isolation and characterization of an anaerobic, cellulolytic bacterium, Clostridium cellulovorans sp. nov. Appl Environ Microbiol 48, 88-93.

Van Ginkel, S., Sung, S. \& Lay, J. J. (2001). Biohydrogen production as a function of $\mathrm{pH}$ and substrate concentration. Environ Sci Technol 35, 4726-4730.

Yan, J., Rash, B. A., Rainey, F. A. \& Moe, W. M. (2009). Isolation of novel bacteria within the Chloroflexi capable of reductive dechlorination of 1,2,3-trichloropropane. Environ Microbiol 11, 833-843. 